\title{
Placenta histopathology in SARS-CoV-2 infection: analysis of a consecutive series and comparison with control cohorts
}

\author{
Luca Bertero ${ }^{1} \cdot$ Fulvio Borella ${ }^{2}$ - Giovanni Botta ${ }^{3}$ - Andrea Carosso ${ }^{2}$ - Stefano Cosma ${ }^{2} \cdot$ Marialuisa Bovetti $^{2}$. \\ Marco Carosso ${ }^{2}$. Giancarlo Abbona ${ }^{3} \cdot$ Giammarco Collemi $^{1} \cdot$ Mauro Papotti $^{4} \cdot$ Paola Cassoni $^{1}$ (D) $\cdot$ Chiara Benedetto $^{2}$
}

Received: 28 October 2020 / Revised: 14 March 2021 / Accepted: 30 March 2021 / Published online: 1 May 2021

(C) The Author(s) 2021

\begin{abstract}
Infection by SARS-CoV-2 has been shown to involve a wide range of organs and tissues, leading to a kaleidoscope of clinical conditions. Within this spectrum, an involvement of the fetal-maternal unit could be expected, but, so far, the histopathological evaluation of placentas delivered by women with SARS-CoV-2 infection did not show distinct hallmarks. A consecutive series of 11 placentas, delivered by 10 women with COVID-19 admitted to our Obstetrics and Gynecology clinic have been investigated and compared to a control cohort of 58 pre-COVID-19 placentas and 28 placentas delivered by women who had a previous cesarean section. Four out of eleven placentas showed changes consistent with chronic villitis/villitis of unknown etiology (VUE), while in one case, chronic histiocytic intervillositis was diagnosed. Thrombo-hemorrhagic alterations were observed in a subset of cases. Compared to the control cohort, chronic villitis/VUE $(p<0.001)$, chronic deciduitis $(p=0.023)$, microvascular thrombosis $(p=0.003)$, presence of infarction areas $(p=0.047)$ and of accelerated villous maturation $(p=0.005)$ showed higher frequencies in placentas delivered by women with COVID-19. Chronic villitis/VUE $(p=0.003)$ and accelerated villous maturation ( $p=0.019$ ) remained statistically significant by restricting the analysis to placentas delivered after a previous cesarean section. The observed differences in terms of pathological findings could be consistent with SARS-CoV-2 pathogenesis, but just a subset of alterations remained statistically significant after adjusting for a previous cesarean section. A careful consideration of potential confounders is warranted in future studies exploring the relationship between COVID-19 and pregnancy.
\end{abstract}

Keywords COVID-19 $\cdot$ SARS-CoV-2 $\cdot$ Histopathology $\cdot$ Thrombosis $\cdot$ Inflammation $\cdot$ Obstetrics

Luca Bertero, Fulvio Borella, Paola Cassoni and Chiara Benedetto contributed equally to this work.

Paola Cassoni

paola.cassoni@unito.it

1 Pathology Unit, Department of Medical Sciences, University of Turin and "Città della Salute e della Scienza di Torino" University Hospital, Turin, Italy

2 Obstetrics and Gynecology 1U, Department of Surgical Sciences, Sant'Anna Hospital, University of Turin and "Città della Salute e della Scienza di Torino" University Hospital, Turin, Italy

3 Pathology Unit, "Città della Salute e della Scienza di Torino" University Hospital, Turin, Italy

4 Pathology Unit, Department of Oncology, University of Turin and "Città della Salute e della Scienza di Torino" University Hospital, Turin, Italy

\section{Introduction}

On March 11, 2020, due do the rapid escalation of the coronavirus disease 2019 (COVID-19) outbreak, the World Health Organization (WHO) declared a pandemic [61]. COVID-19 is caused by the severe acute respiratory syndrome coronavirus 2 (SARS-CoV-2), a betacoronavirus similar to SARS-CoV and MERS-CoV, with multiple possible transmission routes and characterized by a high infectivity $[59,62]$.

In terms of maternal outcomes, data derived from initial cohorts suggested that COVID-19 clinical course in this group of patients is similar to non-pregnant women $[11,16,17,23$, $28,40]$, but not all data are reassuring. Seven maternal deaths were reported among nine pregnant women with severe COVID-19 [32], and an analysis of a Swedish cohort suggested an increased risk of being admitted to an intensive care unit [relative risk (RR): 5.4; 95\% Confidence Interval (CI) 2.89-10.08] and of receiving invasive mechanical ventilation (RR: 4.0; 95\%; CI 1.75-9.14) for pregnant women with 
COVID-19 compared to non-pregnant women of similar age $[19,60]$.

The role of SARS-CoV-2 in the first trimester of pregnancy has also been investigated and present data do not suggest an increased spontaneous abortion risk [21], but the long-term consequences are currently unknown and, in the endemic areas, tests for SARS-CoV-2 should be offered to all pregnant women to investigate this open question [20].

Concerning neonatal outcomes, fetal and respiratory distress as well as thrombocytopenia accompanied by abnormal liver function and even death have been described [64]. In addition, evidence of a higher incidence of preterm birth has been reported $[25,29,63]$ as well as cases of SARS-CoV-2 vertical transmission $[5,12-14,26,58]$, but this seems to be an uncommon occurrence $[24,25,63]$.

High expression of proteins (ACE2/TMPRSS2) required for SARS-CoV-2 cell entry has been observed in maternalfetal interface tissues [42], and placental infection by SARSCoV-2 has been demonstrated in a minority of cases $[1,2,27$, $33,55,58]$.

To date, placental histopathology in COVID-19 has been investigated $[6,7,18,22,31,33,47,48,53,54]$, but specific features or hallmarks have not been identified. Nevertheless, the inflammatory activation and the increased thrombotic risk described in patients with COVID-19 $[35,52,57]$ make the placenta a potential target of pathophysiological phenomena which could affect pregnancy outcomes.

The aim of this work was to evaluate a consecutive series of placentas delivered at our institution from women with COVID-19 infection and compare these data with a preCOVID-19 control series.

\section{Methods}

Our study is based on the pathological analysis of 11 consecutive placentas delivered from 10 women affected by COVID19 and admitted to the Obstetrics and Gynecology clinic of S. Anna Hospital - "Città della Salute e delle Scienza di Torino", University of Turin from March 22, 2020 to July 17, 2020. Sample collection was performed within the framework of the "SARS-CoV-2 infection during pregnancy and puerperium: an Italian Obstetric Surveillance System (ItOSS)" study by the Italian National Institute of Health. All patients showed symptomatic COVID-19 disease confirmed by a nasopharyngeal swab according to World Health Organization (WHO) guidelines. SARS-CoV-2 RNA was detected using an automated real-time RT-PCR assay [DiaSorin Molecular Simplexa ${ }^{\text {TM }}$ COVID-19 Direct, target genes S and ORF1ab]. All placentas and newborns were tested for SARS-CoV-2 with the same assay while a rectal swab was only performed on the patient whose infant resulted positive to SARS-CoV-2 to investigate the potential route of infection. Pathological examination was performed according to routine procedures and immunohistochemistry was set up on a BenchMark ULTRA platform (Ventana Medical Systems Inc., Tucson, AZ, USA).

Clinical records of our Pathology unit (“Città della Salute e della Scienza" University Hospital, Turin, Italy) were searched to select a control cohort. Placentas submitted to histopathological examination between March 2019 and July 2019 were screened and cases without significant maternal comorbidities (e.g., hypertension, diabetes mellitus, infections during pregnancy) were collected $(n=60)$. Two cases with a gestational age $<30$ weeks were excluded to match the groups for this parameter. Since the rate of previous cesarean sections was significantly higher in the COVID-19 group, control cases with this characteristic and without significant maternal comorbidities or abnormal placental implantation were selected to define a further control group. To reach a 4:1 control to cases ratio for this group, the search was expanded to the same months of 2018 .

The study was conducted in accordance with The Code of Ethics of the World Medical Association (Declaration of Helsinki and following amendments) for studies involving humans and within the guidelines and regulations defined by the Research Ethics Committee of the University of Turin. Patients signed a written informed consent. Data supporting study results are included within the manuscript.

Statistical analyses included the use of the $t$-test for unpaired variables and Fisher's exact test for comparison of continuous and categorical variables [Stata/MP 15.0 Statistical Software (STATA, College Station, TX, USA)]. Statistical significance was defined as a two-tailed $p$ value of $<0.05$.

\section{Results}

\section{Case series - general features}

The clinical features of the 10 pregnant women affected by COVID-19 and who delivered the 11 analyzed placentas are reported in Table 1. Placental weight percentiles were reported using the nomogram proposed by Almog et al. [3]. No patient had a history of previous thrombosis, systemic autoimmune diseases, recurrent early miscarriages, fetal loss $>10$ week of gestation, or other conditions suggestive of anti-phospholipid antibody syndrome [30]. All patients resulted negative for the following pathogens: HIV, HBV, HCV, cytomegalovirus, Treponema pallidum and Toxoplasma gondii. Among the six full-term and the four preterm patients ( $<37$ weeks as defined by the WHO) [8] admitted to the hospital for delivery, one had preterm premature rupture of membranes (pPROM) and one a twin pregnancy with oligohydramnios. Four patients complained of COVID-19 symptoms at the time of delivery, one patient (Patient 1) became symptomatic one day 


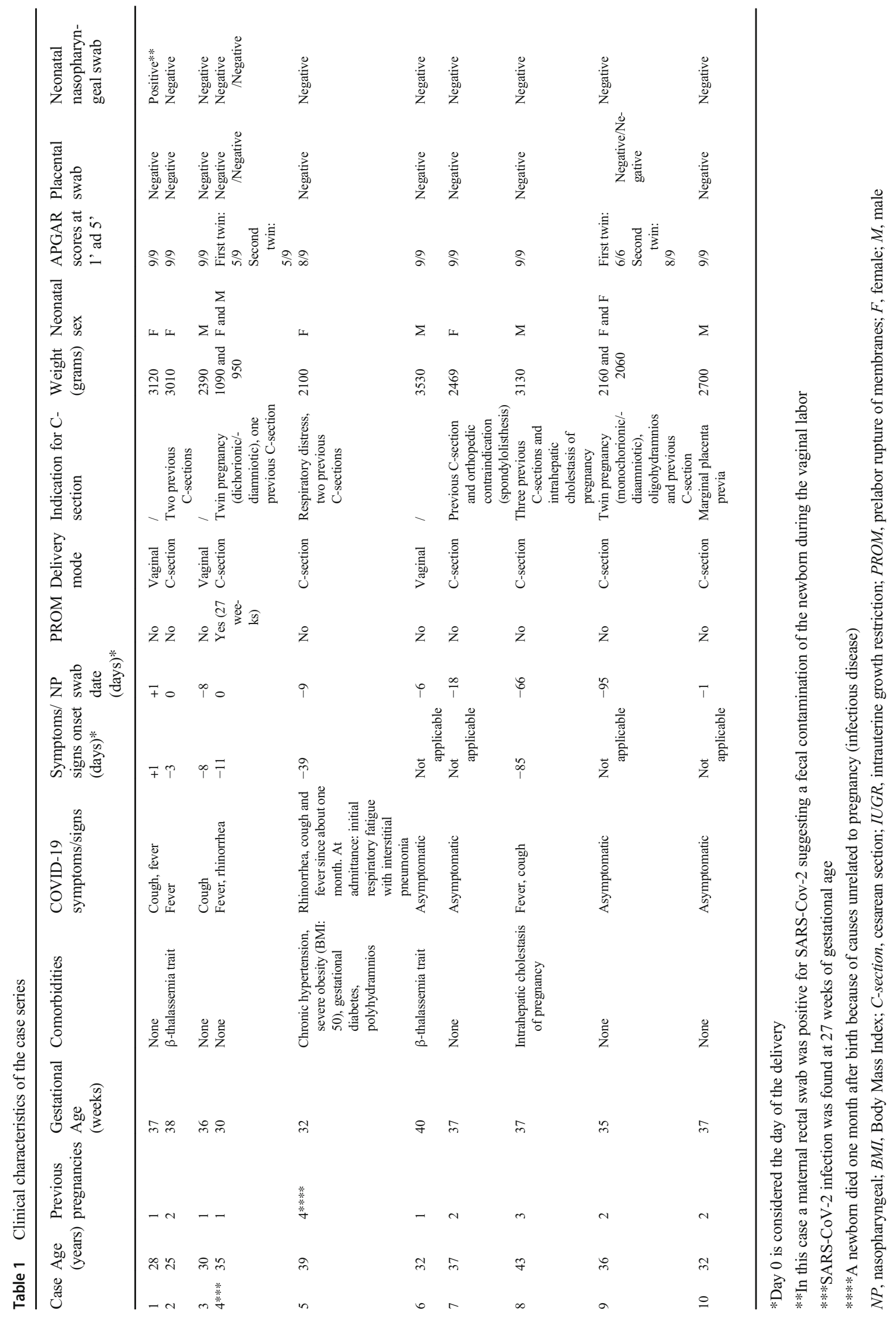


after delivery, one patient (Patient 8) was no longer symptomatic at the time of delivery (COVID-19 symptoms onset at day -95) and the four remaining patients were asymptomatic. All placental swabs were negative for SARS-Cov-2 and only one neonatal nasopharyngeal swab was positive for the virus (as already reported by our group) [12]. In this case, a maternal rectal swab was positive for SARS-Cov-2 suggesting the possibility of a contamination of the newborn during the passage through the birth canal.

The overall relationship between COVID-19 onset and diagnosis, hospital stay and time of delivery is reported on Fig. 1 , while a reference summary of pathological alterations observed in the COVID-19 series is presented in Table 2.

\section{Case 1}

Placenta weight was $590 \mathrm{~g}\left(25^{\text {th }}-50^{\text {th }}\right.$ percentiles $)$ before formalin fixation, lateral dimensions were $16 \times 15 \mathrm{~cm}$ with thickness ranging from $2 \mathrm{~cm}$ to $3 \mathrm{~cm}$. Umbilical cord length was 45 $\mathrm{cm}$, its structure normal and a peripheral insertion was observed. Placental macroscopic features were normal with translucent membranes. Histological examination showed only mild abnormalities including a scant lymphocytic inflammation which involved both the decidua and basal placental villi with initial villous agglutination. Lymphocytes showed a prevalent $\mathrm{T}$ cell cytotoxic (CD8-positive) phenotype. These findings were consistent with chronic villitis (low grade, multifocal since inflammatory foci were present on more than one slide) [37]. Microvascular thrombosis was observed in decidual and villous vessels. Maturation was normal with features suggesting initial hypermaturation.

\section{Case 2}

Placenta weighted $429 \mathrm{~g}\left(<3^{\text {rd }}\right.$ percentile $)$ before fixation, dimensions were $15.5 \times 15 \mathrm{~cm} \times 2$ to $3.1 \mathrm{~cm}$ thickness. Umbilical cord (length: $16 \mathrm{~cm}$ ) and membranes showed a normal morphology. After sectioning, focal and small whitish areas were observed close to the chorial surface and multiple, small (largest dimension $<1 \mathrm{~cm}$ ) hemorrhagic areas were also identified. Microscopically, this case showed morphological features consistent with intervillous hematomas (Fig. 2A) and microvascular thrombosis with intimal proliferations both in decidual vessels and villi (Fig. 2B). Significant foci of lymphocytic inflammation (CD8-positive) were present, involving the decidua and multiple villi (Fig. 2C-2D), findings consistent with chronic villitis (low grade, multifocal) [37]. Villous maturation was as expected for the gestational age.

\section{Case 3}

Placenta weight was $460 \mathrm{~g}$ ( $<3^{\text {rd }}$ percentile) prior to formalin fixation, dimensions: $14 \times 14 \mathrm{~cm} \times 2$ to $3 \mathrm{~cm}$ thickness.
Umbilical cord morphology was normal and insertion central, length: $28 \mathrm{~cm}$. Membranes were translucent. Sectioning showed focal whitish areas (largest dimension: $8 \mathrm{~mm}$ ). Histological features included foci of villous/intervillous lymphocytic inflammation involving both the maternal and the fetal sides as well the decidua; prevalence of CD8-positive cells was observed. Similar to the previous cases, these findings were consistent with chronic villitis (low grade, multifocal) [37]. Features suggestive of decidual vasculopathy and of chronic malperfusion were also present (thrombo-hemorrhagic alterations in decidual vessels, villous infarction, trophoblastic loss and focal thrombi). Villous maturation was within normal range with just focal chorangiosis.

\section{Case 4}

The first placenta weighted $410 \mathrm{~g}$ after formalin fixation, dimensions were $16 \times 14 \mathrm{~cm}$ with a thickness ranging 1 to $3 \mathrm{~cm}$. Umbilical cord length was $16 \mathrm{~cm}$ with a normal morphology and central insertion. Membranes presented a greenish discoloration and had a normal insertion. Sectioning showed extensive hemorrhagic subchorial areas consistent with partial placental abruption. Histological examination confirmed the presence of hemorrhagic areas located below the fetal surface, associated with chronic hypoxia signs (intervillous necrotic areas with focal calcifications). Accelerated villous maturation was also focally present. Decidual morphology was normal.

The second placenta weight was $235 \mathrm{~g}$ after fixation and dimensions were $14 \times 15 \mathrm{~cm}$ with thickness ranging between 0.5 and $2.5 \mathrm{~cm}$. Umbilical cord insertion was paracentral, and length was $20 \mathrm{~cm}$. Membranes showed a greenish discoloration similar to the first placenta. Microscopically, features consistent with accelerated villous maturation were noted. No other abnormalities were present.

Placental weights were among the $10^{\text {th }}-25^{\text {th }}$ percentiles (considering the sum of both placentas for twin pregnancies) [3].

\section{Case 5}

Placenta weight was $370 \mathrm{~g}\left(10^{\text {th }}-25^{\text {th }}\right.$ percentiles $)$ after fixation, dimensions: $15 \times 12 \mathrm{~cm}$ with a thickness ranging between 1 to $3.2 \mathrm{~cm}$. Umbilical cord length was $18 \mathrm{~cm}$ with a paracentral insertion. Membranes appearance was normal. After sectioning, focal abruption was observed (Fig. 3A). Histological examination showed intervillous histiocytic infiltration (CD68-positive) with perivillous fibrin deposition (Fig. 3B-3C), a finding consistent with chronic histiocytic intervillositis. Areas showing villous agglutination, loss of trophoblasts and focal microcalcifications were also observed (Fig. 3D). Focal features of accelerated villous maturation were also present. 
Table 2 Pathological findings observed in the COVID-19 case series

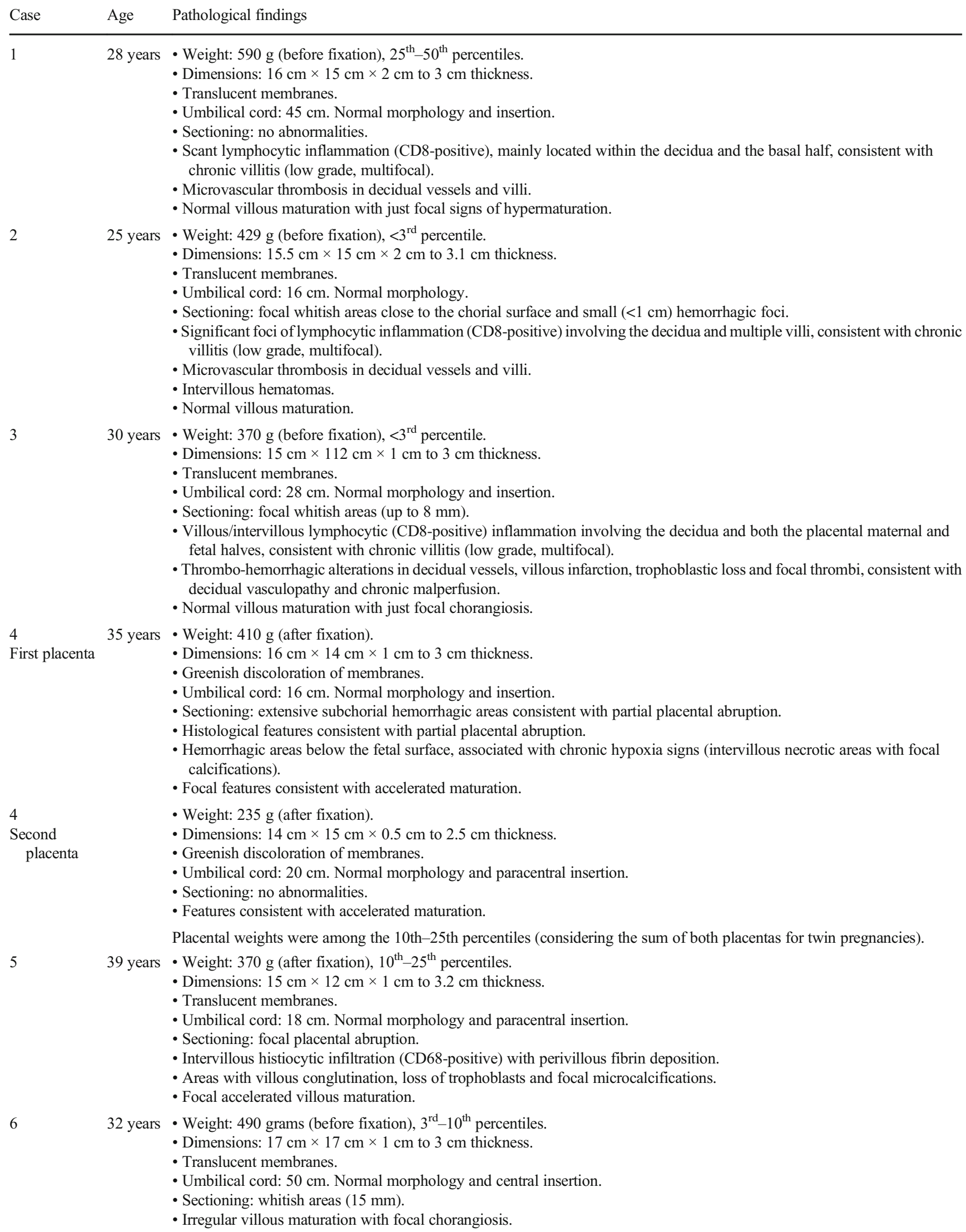

- Thrombo-hemorrhagic alterations in decidual vessels, villous infarction, trophoblastic loss and focal thrombi, consistent with decidual vasculopathy and chronic malperfusion.

- Normal villous maturation with just focal chorangiosis.

435 years - Weight: $410 \mathrm{~g}$ (after fixation).

First placenta $\quad$ Dimensions: $16 \mathrm{~cm} \times 14 \mathrm{~cm} \times 1 \mathrm{~cm}$ to $3 \mathrm{~cm}$ thickness.

- Greenish discoloration of membranes.

- Umbilical cord: $16 \mathrm{~cm}$. Normal morphology and insertion.

- Sectioning: extensive subchorial hemorrhagic areas consistent with partial placental abruption.

- Histological features consistent with partial placental abruption.

- Hemorrhagic areas below the fetal surface, associated with chronic hypoxia signs (intervillous necrotic areas with focal calcifications).

- Focal features consistent with accelerated maturation.

4

Second placenta

-Weight: $235 \mathrm{~g}$ (after fixation).

- Dimensions: $14 \mathrm{~cm} \times 15 \mathrm{~cm} \times 0.5 \mathrm{~cm}$ to $2.5 \mathrm{~cm}$ thickness.

- Greenish discoloration of membranes.

- Umbilical cord: $20 \mathrm{~cm}$. Normal morphology and paracentral insertion.

- Sectioning: no abnormalities.

- Features consistent with accelerated maturation.

Placental weights were among the 10th-25th percentiles (considering the sum of both placentas for twin pregnancies).

- Dimensions: $15 \mathrm{~cm} \times 12 \mathrm{~cm} \times 1 \mathrm{~cm}$ to $3.2 \mathrm{~cm}$ thickness.

- Translucent membranes.

- Umbilical cord: $18 \mathrm{~cm}$. Normal morphology and paracentral insertion.

- Sectioning: focal placental abruption.

- Intervillous histiocytic infiltration (CD68-positive) with perivillous fibrin deposition.

- Areas with villous conglutination, loss of trophoblasts and focal microcalcifications.

- Focal accelerated villous maturation.

32 years - Weight: 490 grams (before fixation), $3^{\text {rd }}-10^{\text {th }}$ percentiles.

- Dimensions: $17 \mathrm{~cm} \times 17 \mathrm{~cm} \times 1 \mathrm{~cm}$ to $3 \mathrm{~cm}$ thickness.

- Translucent membranes.

- Umbilical cord: $50 \mathrm{~cm}$. Normal morphology and central insertion.

- Sectioning: whitish areas (15 mm).

- Irregular villous maturation with focal chorangiosis. 
Table 2 (continued)

\begin{tabular}{|c|c|c|}
\hline Case & Age & Pathological findings \\
\hline & & $\begin{array}{l}\text { - Focal intervillous infarction. } \\
\text { - Focal villous calcifications. }\end{array}$ \\
\hline 7 & 37 years & $\begin{array}{l}\text { - Weight: } 400 \mathrm{~g} \text { (before fixation), }<3^{\text {rd }} \text { percentile. } \\
\text { - Dimensions: } 16 \mathrm{~cm} \times 13 \mathrm{~cm} \times 1 \mathrm{~cm} \text { to } 4 \mathrm{~cm} \text { thickness. } \\
\text { - Translucent membranes. } \\
\text { - Umbilical cord: } 18 \mathrm{~cm} \text {. Normal morphology and marginal insertion. } \\
\text { - Sectioning: focal congestion area. } \\
\text { - Widespread chorangiosis. } \\
\text { - Avascular villi with sclerosis. } \\
\text { - Vascular stenosis and hypertrophy of stem villi. } \\
\text { - Findings consistent with umbilical blood flow restriction. }\end{array}$ \\
\hline 8 & 43 years & $\begin{array}{l}\text { - Weight: } 520 \mathrm{~g} \text { (before fixation), } 10^{\text {th }}-25^{\text {th }} \text { percentiles. } \\
\text { - Dimensions: } 16 \mathrm{~cm} \times 14 \mathrm{~cm} \times 2 \mathrm{~cm} \text { to } 3.5 \mathrm{~cm} \text { thickness. } \\
\text { - Yellowish membranes. } \\
\text { - Umbilical cord: } 37 \mathrm{~cm} \text {. Normal morphology and marginal insertion. } \\
\text { - Sectioning: no specific alterations. } \\
\text { - Focal villous hypermaturation. } \\
\text { - Focal villous agglutination. }\end{array}$ \\
\hline 9 & 36 years & $\begin{array}{l}\text { - Monochorionic diamniotic. } \\
\text { - Weight: } 665 \mathrm{~g} \text { (before fixation), } 3^{\text {rd }}-10^{\text {th }} \text { percentiles for twin deliveries. } \\
\text { - Dimensions: } 19 \mathrm{~cm} \times 16 \mathrm{~cm} \times 3 \mathrm{~cm} \text { to } 4.5 \mathrm{~cm} \text { thickness. } \\
\text { - Translucent membranes. } \\
\text { - First umbilical cord: } 23 \mathrm{~cm} \text {. Hypocoiled with focal edema and marginal insertion. } \\
\text { - Second umbilical cord: } 20 \mathrm{~cm} \text {. Hypocoiled with marginal insertion. } \\
\text { - Sectioning: no specific alterations. } \\
\text { - Lymphocytic infiltration consistent with chronic villitis (low grade, multifocal). } \\
\text { - Accelerated villous maturation associated with focal hypoplasia and increase of syncytial nodes. } \\
\text { - Focal villous sclerosis consistent with fetal thrombotic vasculopathy. } \\
\text { - Focal hemorrhagic area within basal decidua consistent with recent abruption. }\end{array}$ \\
\hline 10 & 32 years & $\begin{array}{l}\text { - Weight: } 440 \mathrm{~g} \text { (before fixation), } 3^{\text {rd }}-10^{\text {th }} \text { percentiles. } \\
\text { - Dimensions: } 16 \mathrm{~cm} \times 15 \mathrm{~cm} \times 1 \mathrm{~cm} \text { to } 3 \mathrm{~cm} \text { thickness. } \\
\text { - Translucent membranes. } \\
\text { - Umbilical cord: } 40 \mathrm{~cm} \text {. Normal morphology and marginal insertion. } \\
\text { - Sectioning: no specific alterations. } \\
\text { - Villous hypoplasia. } \\
\text { - Focal sclerosis consistent with previous placental infarction. }\end{array}$ \\
\hline
\end{tabular}

\section{Case 6}

Placenta weighted $490 \mathrm{~g}\left(3^{\text {rd }}-10^{\text {th }}\right.$ percentiles $)$ before fixation, dimensions: $17 \times 17 \mathrm{~cm}$ with a thickness ranging between 1 and $3 \mathrm{~cm}$. Placental macroscopic features were normal with translucent membranes. Umbilical cord length was $50 \mathrm{~cm}$, with normal morphology and central insertion. The histological examination showed irregular villous maturation with focal chorangiosis, intervillous infarction and villous calcifications.

\section{Case 7}

Placenta weight before fixation was $400 \mathrm{~g}\left(<3^{\text {rd }}\right.$ percentile), while its dimensions were $16 \times 13 \times 1$ to $4 \mathrm{~cm}$ thickness. Membranes were translucent. The umbilical cord exhibited a normal morphology and marginal insertion with a total length of $18 \mathrm{~cm}$. At sectioning, a focal congestion area was observed. Microscopically, features suggestive of umbilical blood flow restriction, like widespread chorangiosis, avascular villi with sclerosis and vascular stenosis together with hypertrophy of stem villi were noticed.

\section{Case 8}

Before fixation placenta weighted $520 \mathrm{~g}\left(10^{\text {th }}-25^{\text {th }}\right.$ percentiles), with total dimensions of $16 \times 14 \mathrm{~cm} \times 2$ to $3.5 \mathrm{~cm}$ thickness. Membranes were yellowish and umbilical cord showed normal morphology and marginal insertion, with a length of $37 \mathrm{~cm}$. No abnormalities were microscopically observed, except for focal villous hypermaturation and focal villous agglutination. 


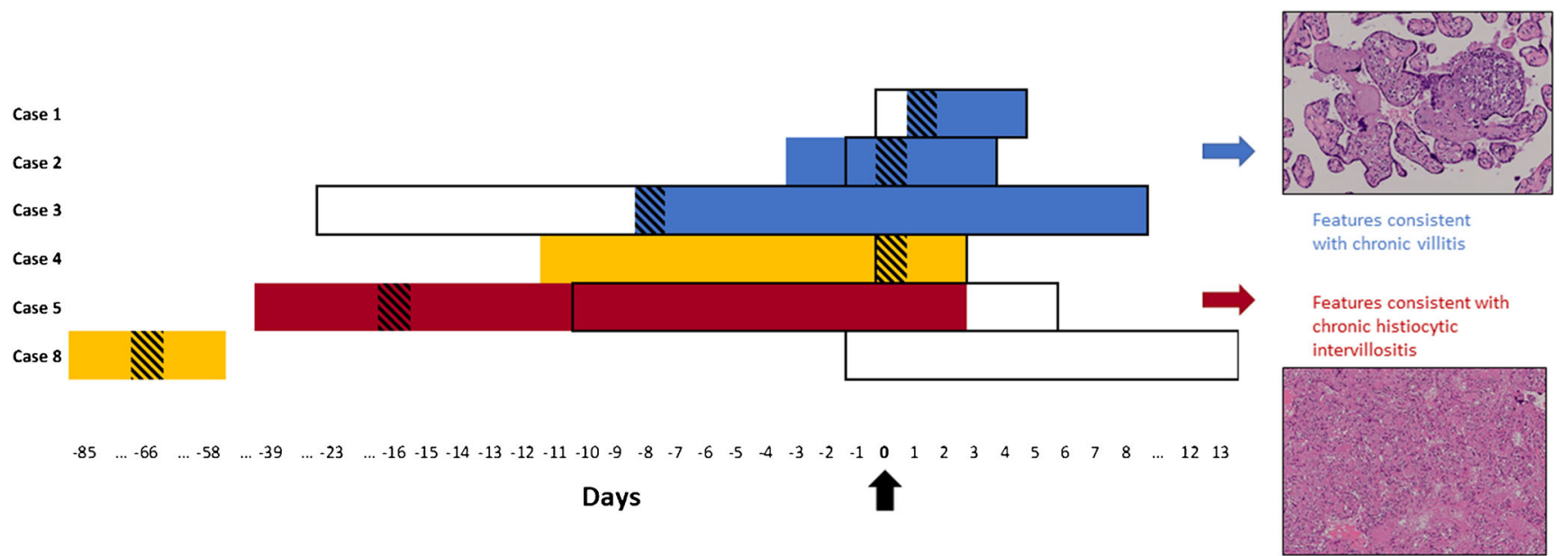

Fig. 1 Outline of COVID-19 clinical course in symptomatic patients and placental pathological findings. Findings consistent with chronic villitis were found in patients with shorter COVID-19 duration and milder symptoms (blue), while chronic histiocytic intervillositis was diagnosed in Case 5 after long-standing and more severe symptoms (red). Patient 4

\section{Case 9}

This placenta was monochorionic diamniotic, with a total weight of $665 \mathrm{~g}$ before fixation, $\left(3^{\text {rd }}-10^{\text {th }}\right.$ percentiles for twin deliveries) and dimensions of $19 \times 16 \mathrm{~cm}$ with a thickness ranging between 3 and $4.5 \mathrm{~cm}$. Membranes were translucent. The two umbilical cords were 23 and $20 \mathrm{~cm}$ in length, both hypocoiled and with marginal insertion. The first was characterized by focal edema. Histological examination showed a lymphocytic infiltration consistent with chronic villitis (low grade, multifocal). Accelerated villous maturation associated with focal hypoplasia and increase of syncytial nodes were also detectable. Features suggestive of fetal thrombotic vasculopathy like focal villous sclerosis were observed. Focal hemorrhagic area within basal decidua consistent with recent abruption was noted.

\section{Case 10}

Placenta weighted $440 \mathrm{~g}\left(3^{\text {rd }}-10^{\text {th }}\right.$ percentiles $)$ before fixation, with dimensions $16 \times 15 \mathrm{~cm} \times 1$ to $3 \mathrm{~cm}$ thickness. Membranes were translucent. Umbilical cord, with normal morphology and marginal insertion, was long $40 \mathrm{~cm}$. Microscopically, this case showed villous hypoplasia and focal sclerosis, a finding consistent with previous placental infarction.

\section{Comparison with pre-COVID-19 control cohorts}

To ascertain the specificity of the observed alterations, a control cohort of 58 pre-COVID-19 placentas was selected among placentas examined between March and July 2019, and this cohort was compared with COVID-19 placentas and patient 8 showed unspecific placental findings (yellow). Black arrow (Day 0): delivery time. Black rectangles: hospitalization. Colored boxes: days with COVID-19 symptoms. Striped boxes: time of nasopharyngeal swab

(Table 3). General characteristics were similar between the two groups $(p>0.05)$ except for the rate of previous cesarean sections which was higher in COVID-19 cases $(p=0.003)$. Regarding the observed pathological alterations, the incidence of VUE $(p<0.001)$, chronic deciduitis $(p=0.023)$, microvascular thrombosis $(p=0.003)$, presence of infarction areas $(p=$ $0.047)$ and of accelerated villous maturation $(p=0.005)$ showed higher frequencies in placentas delivered by women with COVID-19.

Considering the significant difference in terms of previous cesarean sections, the COVID-19 series was compared with a further pre-COVID-19 control series with this characteristic ( $n$ =28). Characteristics of this cohort are reported in Table 4 . Only differences in terms of presence of chronic villitis/VUE $(p=0.035)$ and of accelerated villous maturation $(p=0.019)$ retained their statistically significance.

\section{Discussion}

In this study we report the pathological findings observed in eleven consecutive placentas delivered by ten women affected by COVID-19. Inflammatory and thrombo-hemorrhagic alterations were the most frequent and peculiar pathological changes we observed in our series compared to control samples, but only chronic villitis/VUE and accelerated villous maturation retained statistical significance after restricting the analysis to placentas delivered after a previous cesarean section.

In 5 cases we found microscopic signs of inflammation involving the decidua and the chorial villi: four out of five cases showed a CD8-positive T cell lymphocytic infiltrate, while in the remaining case a chronic histiocytic intervillositis 




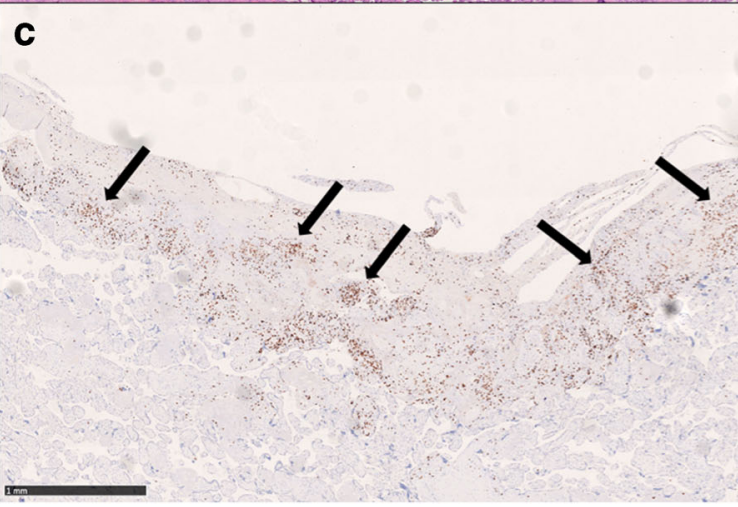

Fig. 2 Pathological findings of Case 2. Placental intervillous hematomas (arrows) (A: HE, 20X) and microvascular thrombosis (arrows) (B: HE, 100X) were observed. Significant foci of decidual and villous

was identified. None of these five patients had comorbidities, other than SARS-CoV-2 infection, which could justify the presence of placental inflammation. The presence of an inflammatory lymphocytic infiltrate (cytotoxic CD8+ T cell lymphocytes in particular, as observed in our series) and of villous damage is consistent with the diagnosis of chronic villitis [10,39]. Chronic villitis etiology can be related to an undergoing infection, although in most cases, it is not possible to identify the specific etiopathogenetic agent: these cases are defined as "villitis of unknown etiology" (VUE) and can be found in 2-33.8\% of placentas [38]. Compared to our control cohort, COVID-19 positive cases had a statistically significant higher frequency of this condition $(p<0.001)$.

Viruses are the most frequent cause of chronic villitis secondary to maternal infections: varicella zoster, herpes simplex virus, cytomegalovirus, and influenza $\mathrm{A} / \mathrm{H} 1 \mathrm{~N} 1$, have been found to be associated with this condition $[4,9,45,56]$. Little is known about the association between placental pathology and coronavirus infection. Seven placentas from coronavirus-infected women during the 2002-2004 SARS outbreak have been previously described [49]: histological examination found no abnormalities in $2 / 7$, an increase in subchorionic and intervillous fibrin in $3 / 7$, and massive thrombotic vasculopathy associated with intra-uterine growth restriction (IUGR) in the remaining $2 / 7$ cases. No signs of chronic villitis were detected in any case and the same is true d

inflammation were also present (arrows) (C: anti-CD8 IHC, 30X; D: anti-CD8 IHC, 80X), consistent with multifocal, low grade chronic villitis

for MERS infections [36]. Moreover, considering experiences derived from influenza $\mathrm{A} / \mathrm{H} 1 \mathrm{~N} 1$ infections in pregnancy, characterized by the activation of cellular immune response with release of inflammatory cytokines that lead to indirect placental damage [45], it stands to reason that SARS-CoV-2 may play an equivalent role in these histological examinations, because of intrinsic active virus replication and/or through indirect activity of inflammatory cytokines [43].

In the remaining case with inflammatory abnormalities, features consistent with chronic histiocytic intervillositis were identified. This rare entity is usually associated with maternal immunologic conditions like systemic lupus erythematosus, lupus anticoagulant and antiphospholipid syndrome [44, 46], while this patient's significant comorbidities (chronic hypertension, severe obesity, and gestational diabetes) are not. Despite the different types of inflammatory infiltrate (histiocytic versus lymphocytic) and of etiologies (chronic histiocytic intervillositis is usually not related to viral infections); this pathological entity is frequently associated with chronic villitis (30 to $50 \%$ of cases), supporting a potential overlap in terms of involved immunologic pathways [41, 50]. Moreover, alveolar histiocytic infiltration is a frequent autoptic hallmark of SARS-CoV-2 infection [15]. Of note, despite its rarity, other cases of histiocytic intervillositis have been reported in placentas delivered by a SARS-CoV-2positive women $[34,47]$. 


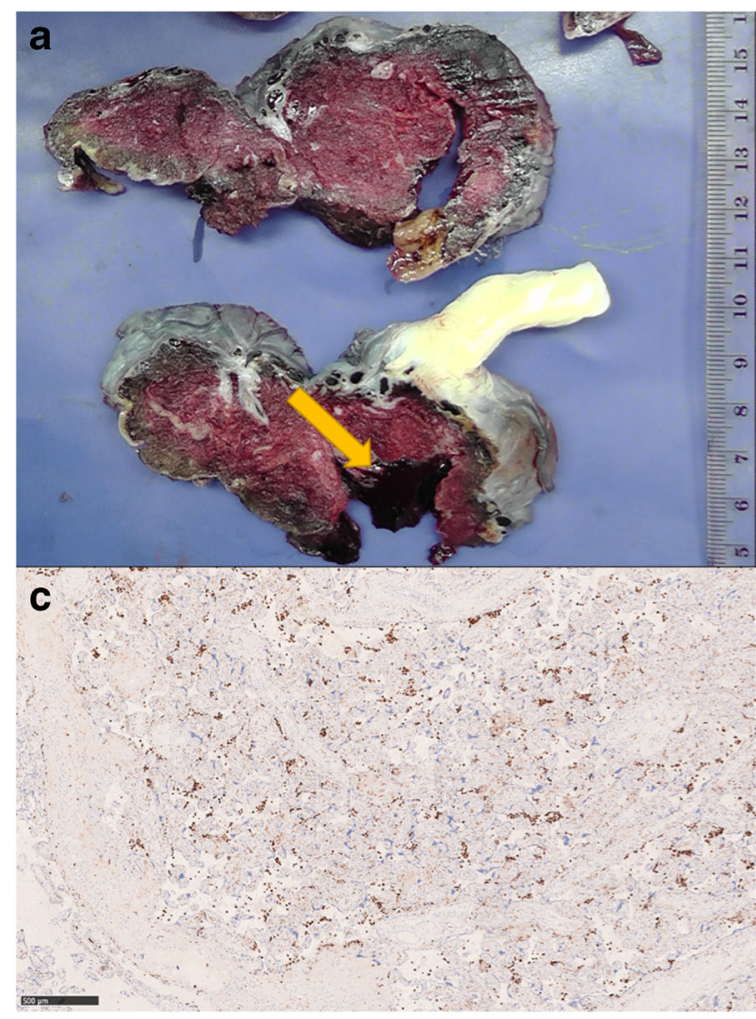

Fig. 3 Pathological findings of Case 5. Focal placental abruption was noted during grossing (arrow) (A). Diffuse intervillous histiocytic infiltration was present consistently with the diagnosis of chronic

Regarding the thrombo-hemorrhagic alterations, decidual microvascular thrombi were present in 3 cases, a significantly different frequency compared to the control cohort $(p=0.003)$ [15]. The relationship between COVID-19 and systemic coagulopathy with a thrombo-inflammatory state has been well documented $[53,54]$ and placental thromboses were also described in two cases of SARS-CoV during the previous outbreak as previously listed. Severe endothelial damage has also been described in lungs from COVID-19 patients associated with thrombosis and microangiopathy [55]. Placental microthrombosis may also be associated with antiphospholipid syndrome [42], but no patient in our series had a medical history or comorbidities suggesting the presence of antiphospholipid antibodies. Other findings, like placental hematomas, are common findings and probably unrelated to the SARS-CoV-2 infection. Concerning other thrombo-hemorrhagic findings like placental abruptions, an association between this condition and thrombophilia has been suggested [56] and an episode of placental abruption in a twin pregnancy complicated by COVID-19 was reported [57]. Features consistent with maternal vascular malperfusion, like accelerated villous maturation, were also more frequently observed within our series compared to the control cohort, but this hallmark can be secondary to multiple physiological and pathological conditions like twin pregnancy, hypertension, smoking and pre-eclampsia.

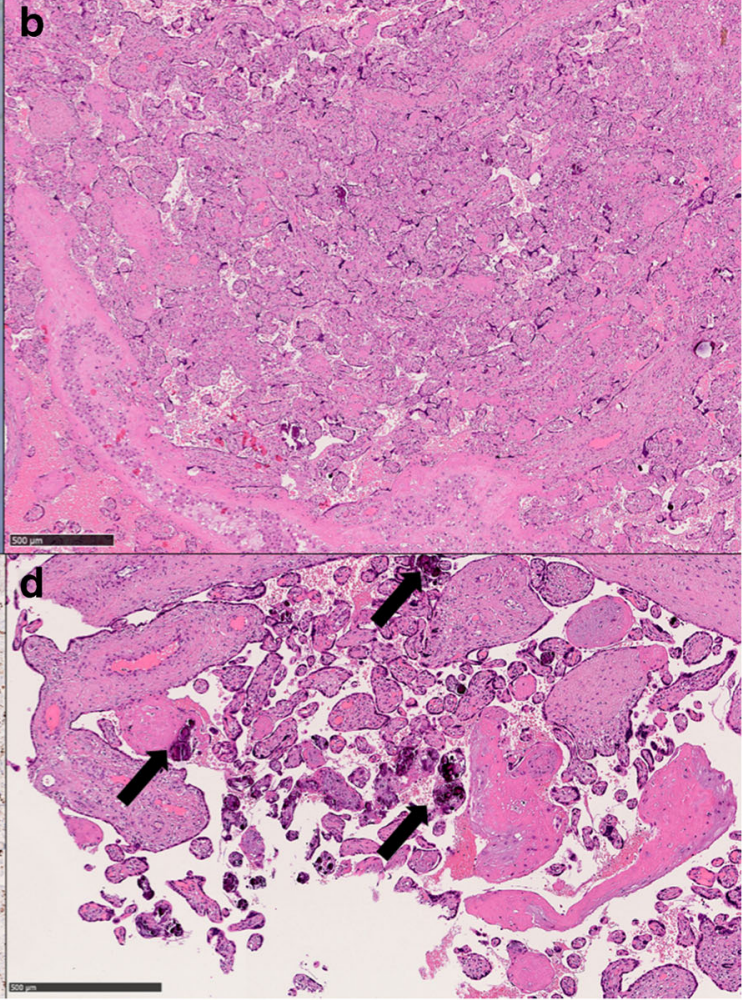

histiocytic intervillositis (B: HE, 40X; C: anti-CD68 IHC, 40X). Villous agglutination with loss of trophoblasts and microcalcification was also observed (arrows) (D: HE, 70X)

Regarding the previously reported series of placentas delivered by women with SARS-CoV-2 infection, no specific findings have been reported so far $[6,22,31,33,47,48,53$, 54]. In particular, Hecht et al. examined 19 placentas and found no characteristic histopathological features. This study is specifically relevant because a comprehensive analysis of both SARS-CoV-2 potential receptor/cofactor and viral RNA was performed. ACE2 was found to be commonly expressed by the syncytiotrophoblast, the cytotrophoblast and by scattered extravillous trophoblast. Strong positivity was also observed in maternal vessels. Conversely, TMPRSS2 was rarely and weakly positive in the villous endothelium, while the syncytiotrophoblast of one sample only showed a weak and patchy positivity. Regarding viral presence, SARS-CoV2 RNA was detected in 2 out of 19 samples (one in the syncytiotrophoblast and one, focally, in both the syncytiotrophoblast and the cytotrophoblast) [33]. Viral RNA was also rarely present in the maternal endothelium within the decidua parietalis. These data support that direct placental infection by SARS-CoV-2 is a possible, although rare event. Evidence of potential placental infection by SARS-CoV-2 has also been confirmed by multiple assays, including electron microscopy $[1,55,58]$.

Concerning the comparison of histopathological findings with control cohorts, Hecht et al. compared their COVID-19 placenta samples with both a series of "normal" (uncomplicated term 
Table 3 Comparison of general characteristics and pathological findings between placentas delivered by women with COVID-19 and the pre-COVID19 control cohort

\begin{tabular}{|c|c|c|c|c|c|c|c|}
\hline General characteristics & $\begin{array}{l}\text { COVID-19 } \\
(n=11) \\
\text { Median (range) }\end{array}$ & $\begin{array}{l}\text { Control }(n=58) \\
\text { Median (range) }\end{array}$ & $p$ value & Pathological findings & $\begin{array}{l}\text { COVID- } \\
19 \\
(n=11)\end{array}$ & $\begin{array}{l}\text { Control } \\
(n=58)\end{array}$ & $p$ value \\
\hline Maternal age & $33.5(25-43)$ & $34(18-43)$ & 0.772 & Chronic villitis/VUE & 4 & 0 & $<0.001$ \\
\hline Gestational age & $37(30-40)$ & $37(30-41)$ & 0.313 & Histiocytic intervillositis & 1 & 0 & 0.159 \\
\hline Placental weight & $440(235-665)$ & $482(260-1005)$ & 0.378 & Acute villitis & 0 & 2 & 1.000 \\
\hline Fetal weight & $2586(950-3530)$ & $2630(1380-4920)$ & 0.155 & Chronic deciduitis & 2 & 0 & 0.023 \\
\hline \multirow[t]{11}{*}{ Previous cesarean section(s) } & 7 & 10 & 0.003 & Acute deciduitis & 0 & 5 & 0.585 \\
\hline & & & & Choramniotitis & 0 & 7 & 0.587 \\
\hline & & & & Decidual microvascular thrombosis & 3 & 0 & 0.003 \\
\hline & & & & Intervillous hemorrhage & 3 & 5 & 0.109 \\
\hline & & & & Placental infarction areas & 3 & 3 & 0.047 \\
\hline & & & & Intervillous thrombi/fibrin deposition & 3 & 9 & 0.390 \\
\hline & & & & Chorangiosis & 3 & 7 & 0.192 \\
\hline & & & & Accelerated villous maturation & 4 & 2 & 0.005 \\
\hline & & & & Delayed villous maturation & 1 & 12 & 0.676 \\
\hline & & & & Distal villous hypoplasia & 1 & 0 & 0.159 \\
\hline & & & & Villous edema & 0 & 2 & 1.000 \\
\hline
\end{tabular}

deliveries) and "pathologic" controls (placentas of neonates with a clinical diagnosis of hypoxic ischemic encephalopathy). Interestingly, although the incidence of specific alterations like fetal vascular malperfusion (15\%) was higher in COVID-19 placentas compared with the "normal" controls (5\%), it was similar to the incidence in the "abnormal" cohort (17\%). This finding is similar to ours: despite that the frequencies of multiple histopathological alterations were initially significantly different when comparing them with a general control cohort, only a few of them retained their significance after adjusting for a potential confounding factor (a previous cesarean section). Although the sample size reduction could have played a role, this result highlights the importance of taking into account potential confounding factors before suggesting a causal relationship. For example,

Table 4 Comparison of general characteristics and pathological findings between placentas delivered by women with COVID-19 who had previous cesarean section(s) and a pre-COVID-19 control cohort of placentas delivered by women who had previous cesarean section(s)

\begin{tabular}{|c|c|c|c|c|c|c|c|}
\hline General characteristics & $\begin{array}{l}\text { COVID-19 } \\
(n=7) \\
\text { Median (range) }\end{array}$ & $\begin{array}{l}\text { Control }(n=28) \\
\text { Median (range) }\end{array}$ & $p$ value & Pathological findings & $\begin{array}{l}\text { COVID-19 } \\
(n=7)\end{array}$ & $\begin{array}{l}\text { Control } \\
(n=28)\end{array}$ & $p$ value \\
\hline Maternal age & $36(25-43)$ & $34(26-47)$ & 0.238 & Chronic villitis/VUE & 2 & 0 & 0.035 \\
\hline Gestational age & $35(30-38)$ & $37.5(32-40)$ & 0.0002 & Histiocytic intervillositis & 1 & 0 & 0.200 \\
\hline Placental weight & $410(235-665)$ & $489(236-820)$ & 0.1738 & Acute villitis & 0 & 1 & 0.800 \\
\hline \multirow[t]{12}{*}{ Fetal weight } & $2284.5(950-3130)$ & $2890(1830-4160)$ & 0.09492 & Chronic deciduitis & 1 & 0 & 0.200 \\
\hline & & & & Acute deciduitis & 0 & 0 & - \\
\hline & & & & Choramniotitis & 0 & 1 & 0.800 \\
\hline & & & & Decidual microvascular thrombosis & 1 & 0 & 0.200 \\
\hline & & & & Intervillous hemorrhage & 1 & 0 & 0.200 \\
\hline & & & & Placental infarction areas & 1 & 1 & 0.365 \\
\hline & & & & Intervillous thrombi/fibrin deposition & 2 & 2 & 0.171 \\
\hline & & & & Chorangiosis & 1 & 3 & 0.609 \\
\hline & & & & Accelerated villous maturation & 3 & 1 & 0.019 \\
\hline & & & & Delayed villous maturation & 0 & 6 & 0.232 \\
\hline & & & & Distal villous hypoplasia & 1 & 1 & 0.365 \\
\hline & & & & Villous edema & 0 & 2 & 0.635 \\
\hline
\end{tabular}


abnormal placental implantation is another potential confounding variable which should be considered in future studies. In our cohort, only one case presented this finding (Case $10-$ Marginal placenta previa).

Nevertheless, we detected significantly higher frequencies of chronic villitis/VUE and accelerated villous maturation even after accounting for a previous cesarean section. Recently, also Patberg et al. observed a higher incidence of villitis of unknown etiology (20.8 versus $7.1 \%$ ) compared with a control group of term patients without COVID-19 [51]. This result was also confirmed in a subgroup analysis comparing asymptomatic COVID-19 patients with negative controls, but it did not reach statistical significance in a multivariable comparison adjusting for multiple clinical characteristics. This finding further enhances the importance of analyzing larger series of cases, possibly through dedicated metaanalyses, and adjusting for the effect of potential confounders. Regarding vascular/thrombotic alterations, 2 out of the 3 decidual microvascular thromboses we observed among COVID-19 cases were present in placentas delivered by women who had no previous cesarean section and thus they were independent of this potentially confounding variable. Therefore, the lack of significance observed by restricting the analysis to COVID-19 placentas delivered after a previous cesarean section could be at least partially due to sample size reduction.

Concerning our knowledge about the clinical outcomes of pregnancy in COVID-19 patients, Chen et al. [17] reported the outcomes of a relatively large series of pregnant women affected by COVID-19 observing a high rate $(14 / 68,21 \%)$ of preterm delivery. A systematic review evaluating 41 pregnancies affected by COVID-19 confirmed this observation, reporting preterm birth ( $<37$ weeks) in above $40 \%$ of pregnancies [25]. Finally, even the largest systematic review available on 441 pregnant patients with COVID-19 also found that preterm birth is the most common adverse neonatal outcome (reported in the $21 \%$ of women who delivered) [29]. However, it should be noted that this higher rate of preterm deliveries could be at least partially explained by a different attitude during the early months of the pandemic favoring early delivery by cesarean section because of fear of potential COVID-19 complications.

Finally, the limited sample size and the intrinsically unspecific etiology of most of the observed placental alterations are the main limitations of our study as well of many of those published so far. Larger, multi-institutional prospective studies taking into account the whole set of variables related to SARS-CoV-2 infection (timing, severity, duration...), placental histopathological findings, potential confounders and materno-fetal outcomes are warranted to provide a definitive assessment of the relationship between COVID-19 and pregnancy.
Author contribution GB, PC and CB designed the research protocol; all authors contributed to data collection and analysis; LB, FB, GB, AC and $\mathrm{SC}$ drafted the paper; all authors edited the paper and approved the final version.

Funding The present study was kindly supported by a grant from "Banca del Piemonte" to PC dedicated to COVID-19 research and by the Italian Ministry of University and Research/University of Turin (ex 60\%) to LB. Open access funding provided by Università degli Studi di Torino within the CRUI-CARE Agreement.

\section{Declarations}

Conflict of interest The authors declare no competing interests.

Open Access This article is licensed under a Creative Commons Attribution 4.0 International License, which permits use, sharing, adaptation, distribution and reproduction in any medium or format, as long as you give appropriate credit to the original author(s) and the source, provide a link to the Creative Commons licence, and indicate if changes were made. The images or other third party material in this article are included in the article's Creative Commons licence, unless indicated otherwise in a credit line to the material. If material is not included in the article's Creative Commons licence and your intended use is not permitted by statutory regulation or exceeds the permitted use, you will need to obtain permission directly from the copyright holder. To view a copy of this licence, visit http://creativecommons.org/licenses/by/4.0/.

\section{References}

1. Algarroba GN, Hanna NN, Rekawek P, Vahanian SA, Khullar P, Palaia T, Peltier MR, Chavez MR, Vintzileos AM (2020) Confirmatory evidence of the visualization of severe acute respiratory syndrome coronavirus 2 invading the human placenta using electron microscopy. Am J Obstet Gynecol 223:953-954. https:// doi.org/10.1016/j.ajog.2020.08.106

2. Algarroba GN, Hanna NN, Rekawek P, Vahanian SA, Khullar P, Palaia T, Peltier MR, Chavez MR, Vintzileos AM (2020) Confirmatory evidence of visualization of SARS-CoV-2 virus invading the human placenta using electron microscopy. Am J Obstet Gynecol 223:953-954. https://doi.org/10.1016/j.ajog.2020.08.106

3. Almog B, Shehata F, Aljabri S, Levin I, Shalom-Paz E, Shrim A (2011) Placenta weight percentile curves for singleton and twins deliveries. Placenta 32:58-62. https://doi.org/10.1016/j.placenta. 2010.10.008

4. Altshuler G, Russell P (1975) The human placental villitides: a review of chronic intrauterine infection. Curr Top Pathol 60:64112

5. Alzamora MC, Paredes T, Caceres D, Webb CM, Valdez LM, La Rosa M (2020) Severe COVID-19 during pregnancy and possible vertical transmission. Am J Perinatol 37:861-865. https://doi.org/ $10.1055 / \mathrm{s}-0040-1710050$

6. Baergen RN, Heller DS (2020) Placental pathology in Covid-19 positive mothers: preliminary findings. Pediatr Dev Pathol 23: 177-180. https://doi.org/10.1177/1093526620925569

7. Baud D, Greub G, Favre G, Gengler C, Jaton K, Dubruc E, Pomar L (2020) Second-trimester miscarriage in a pregnant woman with SARS-CoV-2 infection. JAMA. https://doi.org/10.1001/jama. 2020.7233 
8. Beck S, Wojdyla D, Say L, Betran AP, Merialdi M, Requejo JH, Rubens C, Menon R, Van Look PF (2010) The worldwide incidence of preterm birth: a systematic review of maternal mortality and morbidity. Bull World Health Organ 88:31-38. https://doi.org/ 10.2471/BLT.08.062554

9. Becroft DM, Thompson JM, Mitchell EA (2005) Placental villitis of unknown origin: epidemiologic associations. Am J Obstet Gynecol 192:264-271. https://doi.org/10.1016/j.ajog.2004.06.062

10. Boog G (2008) Chronic villitis of unknown etiology. Eur J Obstet Gynecol Reprod Biol 136:9-15. https://doi.org/10.1016/j.ejogrb. 2007.06.018

11. Breslin N, Baptiste C, Gyamfi-Bannerman C, Miller R, Martinez R, Bernstein K, Ring L, Landau R, Purisch S, Friedman AM, Fuchs K, Sutton D, Andrikopoulou M, Rupley D, Sheen JJ, Aubey J, Zork N, Moroz L, Mourad M, Wapner R, Simpson LL, D'Alton ME, Goffman D (2020) COVID-19 infection among asymptomatic and symptomatic pregnant women: two weeks of confirmed presentations to an affiliated pair of New York City hospitals. Am J Obstet Gynecol MFM:100118. https://doi.org/10.1016/j.ajogmf. 2020.100118

12. Carosso A, Cosma S, Borella F, Marozio L, Coscia A, Ghisetti V, Di Perri G, Benedetto C (2020) Pre-labor anorectal swab for SARSCoV-2 in COVID-19 patients: is it time to think about it? Eur J Obstet Gynecol Reprod Biol 249:98-99. https://doi.org/10.1016/j. ejogrb.2020.04.023

13. Carosso A, Cosma S, Serafini P, Benedetto C, Mahmood T (2020) How to reduce the potential risk of vertical transmission of SARSCoV-2 during vaginal delivery? Eur J Obstet Gynecol Reprod Biol 250:246-249. https://doi.org/10.1016/j.ejogrb.2020.04.065

14. Carosso AR, Cosma S, Benedetto C (2020) Vaginal delivery in COVID-19 pregnant women: anorectum as a potential alternative route of SARS-CoV-2 transmission. Am J Obstet Gynecol 223: 612. https://doi.org/10.1016/j.ajog.2020.06.012

15. Carsana L, Sonzogni A, Nasr A, Rossi R, Pellegrinelli A, Zerbi P, Rech R, Colombo R, Antinori S, Corbellino M, Galli M, Catena E, Tosoni A, Gianatti A, Nebuloni M (2020) Pulmonary post-mortem findings in a large series of COVID-19 cases from Northern Italy medRxiv:2020.2004.2019.20054262. https://doi.org/10.1101/ 2020.04.19.20054262

16. Chen H, Guo J, Wang C, Luo F, Yu X, Zhang W, Li J, Zhao D, Xu D, Gong Q, Liao J, Yang H, Hou W, Zhang Y (2020) Clinical characteristics and intrauterine vertical transmission potential of COVID-19 infection in nine pregnant women: a retrospective review of medical records. Lancet 395:809-815. https://doi.org/10. 1016/S0140-6736(20)30360-3

17. Chen L, Li Q, Zheng D, Jiang H, Wei Y, Zou L, Feng L, Xiong G, Sun G, Wang H, Zhao Y, Qiao J (2020) Clinical characteristics of pregnant women with Covid-19 in Wuhan, China. N Engl J Med 382:e100. https://doi.org/10.1056/NEJMc2009226

18. Chen S, Huang B, Luo DJ, Li X, Yang F, Zhao Y, Nie X, Huang BX (2020) Pregnant women with new coronavirus infection: a clinical characteristics and placental pathological analysis of three cases. Zhonghua Bing Li Xue Za Zhi 49:E005. https://doi.org/10. 3760/cma.j.cn112151-20200225-00138

19. Collin J, Bystrom E, Carnahan A, Ahrne M (2020) Pregnant and postpartum women with SARS-CoV-2 infection in intensive care in Sweden. Acta Obstet Gynecol Scand 99:819-822. https://doi.org/ 10.1111/aogs. 13901

20. Cosma S, Borella F, Carosso A, Sciarrone A, Cusato J, Corcione S, Mengozzi G, Preti M, Katsaros D, Di Perri G, Benedetto C (2020) The "scar" of a pandemic: cumulative incidence of COVID-19 during the first trimester of pregnancy. J Med Virol 93:537-540. https://doi.org/10.1002/jmv.26267

21. Cosma S, Carosso AR, Cusato J, Borella F, Carosso M, Bovetti M, Filippini C, D'Avolio A, Ghisetti V, Dip G, Benedetto C (2020) COVID-19 and first trimester spontaneous abortion: a case-control study of 225 pregnant patients. Am J Obstet Gynecol 224:391.e1391.e7. https://doi.org/10.1016/j.ajog.2020.10.005

22. Cribiu FM, Croci GA, Del Gobbo A, Rizzuti T, Iurlaro E, Tondo M, Viscardi A, Bosari S, Ferrero S (2020) Histological characterization of placenta in COVID19 pregnant women. Eur J Obstet Gynecol Reprod Biol 252:619-621. https://doi.org/10.1016/j. ejogrb.2020.06.041

23. Dashraath P, Wong JLJ, Lim MXK, Lim LM, Li S, Biswas A, Choolani M, Mattar C, Su LL (2020) Coronavirus disease 2019 (COVID-19) pandemic and pregnancy. Am J Obstet Gynecol 222:521-531. https://doi.org/10.1016/j.ajog.2020.03.021

24. Della Gatta AN, Rizzo R, Pilu G, Simonazzi G (2020) COVID19 during pregnancy: a systematic review of reported cases. Am J Obstet Gynecol 223:36-41. https://doi.org/10.1016/j.ajog.2020. 04.013

25. Di Mascio D, Khalil A, Saccone G, Rizzo G, Buca D, Liberati M, Vecchiet J, Nappi L, Scambia G, Berghella V, D'Antonio F (2020) Outcome of coronavirus spectrum infections (SARS, MERS, COVID 1 -19) during pregnancy: a systematic review and metaanalysis Am J Obstet Gynecol MFM:100107. https://doi.org/10. 1016/j.ajogmf.2020.100107

26. Dong L, Tian J, He S, Zhu C, Wang J, Liu C, Yang J (2020) Possible vertical transmission of SARS-CoV-2 from an infected mother to her newborn. JAMA. https://doi.org/10.1001/jama. 2020.4621

27. Facchetti F, Bugatti M, Drera E, Tripodo C, Sartori E, Cancila V, Papaccio M, Castellani R, Casola S, Boniotti MB, Cavadini P, Lavazza A (2020) SARS-CoV2 vertical transmission with adverse effects on the newborn revealed through integrated immunohistochemical, electron microscopy and molecular analyses of Placenta. EBioMedicine 59:102951. https://doi.org/10.1016/j.ebiom.2020. 102951

28. Ferrazzi EM, Frigerio L, Cetin I, Vergani P, Spinillo A, Prefumo F, Pellegrini E, Gargantini G (2020) COVID-19 Obstetrics Task Force, Lombardy, Italy: executive management summary and short report of outcome. Int J Gynaecol Obstet 149:377-378. https://doi. org/10.1002/ijgo.13162

29. Gajbhiye R, Modi D, Mahale S (2020) Pregnancy outcomes, newborn complications and maternal-fetal transmission of SARS-CoV2 in women with COVID-19: a systematic review of 441 cases medRxiv:2020.2004.2011.20062356. https://doi.org/10.1101/ 2020.04.11.20062356

30. Garcia D, Erkan D (2018) Diagnosis and management of the antiphospholipid syndrome. N Engl J Med 378:2010-2021. https://doi.org/10.1056/NEJMra1705454

31. Gulersen M, Prasannan L, Tam HT, Metz CN, Rochelson B, Meirowitz N, Shan W, Edelman M, Millington KA (2020) Histopathological evaluation of placentas after diagnosis of maternal SARS-CoV-2 infection Am J Obstet Gynecol MFM:100211. https://doi.org/10.1016/j.ajogmf.2020.100211

32. Hantoushzadeh S, Shamshirsaz AA, Aleyasin A, Seferovic MD, Aski SK, Arian SE, Pooransari P, Ghotbizadeh F, Aalipour S, Soleimani Z, Naemi M, Molaei B, Ahangari R, Salehi M, Oskoei AD, Pirozan P, Darkhaneh RF, Laki MG, Farani AK, Atrak S, Miri MM, Kouchek M, Shojaei S, Hadavand F, Keikha F, Hosseini MS, Borna S, Ariana S, Shariat M, Fatemi A, Nouri B, Nekooghadam SM, Aagaard K (2020) Maternal death due to COVID-19 disease. Am J Obstet Gynecol 223:109.e1-109.e16. https://doi.org/10. 1016/j.ajog.2020.04.030

33. Hecht JL, Quade B, Deshpande V, Mino-Kenudson M, Ting DT, Desai N, Dygulska B, Heyman T, Salafia C, Shen D, Bates SV, Roberts DJ (2020) SARS-CoV-2 can infect the placenta and is not associated with specific placental histopathology: a series of 19 placentas from COVID-19-positive mothers. Mod Pathol 33: 2092-2103. https://doi.org/10.1038/s41379-020-0639-4 
34. Hosier H, Farhadian SF, Morotti RA, Deshmukh U, Lu-Culligan A, Campbell KH, Yasumoto Y, Vogels CB, Casanovas-Massana A, Vijayakumar P, Geng B, Odio CD, Fournier J, Brito AF, Fauver JR, Liu F, Alpert T, Tal R, Szigeti-Buck K, Perincheri S, Larsen C, Gariepy AM, Aguilar G, Fardelmann KL, Harigopal M, Taylor HS, Pettker CM, Wyllie AL, Cruz CD, Ring AM, Grubaugh ND, Ko AI, Horvath TL, Iwasaki A, Reddy UM, Lipkind HS (2020) SARS-CoV-2 infection of the placenta. J Clin Invest 130:49474953. https://doi.org/10.1172/JCI139569

35. Huang C, Wang Y, Li X, Ren L, Zhao J, Hu Y, Zhang L, Fan G, Xu J, Gu X, Cheng Z, Yu T, Xia J, Wei Y, Wu W, Xie X, Yin W, Li H, Liu M, Xiao Y, Gao H, Guo L, Xie J, Wang G, Jiang R, Gao Z, Jin Q, Wang J, Cao B (2020) Clinical features of patients infected with 2019 novel coronavirus in Wuhan, China. Lancet 395:497-506. https://doi.org/10.1016/S0140-6736(20)30183-5

36. Jeong SY, Sung SI, Sung JH, Ahn SY, Kang ES, Chang YS, Park WS, Kim JH (2017) MERS-CoV infection in a pregnant woman in Korea. J Korean Med Sci 32:1717-1720. https://doi.org/10.3346/ jkms.2017.32.10.1717

37. Khong TY, Mooney EE, Ariel I, Balmus NC, Boyd TK, Brundler MA, Derricott H, Evans MJ, Faye-Petersen OM, Gillan JE, Heazell AE, Heller DS, Jacques SM, Keating S, Kelehan P, Maes A, McKay EM, Morgan TK, Nikkels PG, Parks WT, Redline RW, Scheimberg I, Schoots MH, Sebire NJ, Timmer A, Turowski G, van der Voorn JP, van Lijnschoten I, Gordijn SJ (2016) Sampling and definitions of placental lesions: Amsterdam Placental Workshop Group Consensus Statement. Arch Pathol Lab Med 140:698-713. https://doi.org/10.5858/arpa.2015-0225-CC

38. Khong TY, Mooney EE, Nikkels PGJ, Morgan TK, Gordijn SJ (2019) Pathology of the placenta: a practical guide. Springer, Cham, Switzerland

39. Kim CJ, Romero R, Chaemsaithong P, Kim JS (2015) Chronic inflammation of the placenta: definition, classification, pathogenesis, and clinical significance. Am J Obstet Gynecol 213:S53-S69. https://doi.org/10.1016/j.ajog.2015.08.041

40. Knight M, Bunch K, Vousden N, Morris E, Simpson N, Gale C, O'Brien P, Quigley M, Brocklehurst P, Kurinczuk JJ (2020) Characteristics and outcomes of pregnant women hospitalised with confirmed SARS-CoV-2 infection in the UK: a national cohort study using the UK Obstetric Surveillance System (UKOSS) medRxiv:2020.2005.2008.20089268. https://doi.org/10.1101/ 2020.05.08.20089268

41. Labarrere CA, Hardin JW, Haas DM, Kassab GS (2015) Chronic villitis of unknown etiology and massive chronic intervillositis have similar immune cell composition. Placenta 36:681-686. https://doi. org/10.1016/j.placenta.2015.03.008

42. Li M, Chen L, Zhang J, Xiong C, Li X (2020) The SARS-CoV-2 receptor ACE2 expression of maternal-fetal interface and fetal organs by single-cell transcriptome study. PLoS One 15:e230295. https://doi.org/10.1371/journal.pone.0230295

43. Liu H, Wang LL, Zhao SJ, Kwak-Kim J, Mor G, Liao AH (2020) Why are pregnant women susceptible to COVID-19? An immunological viewpoint. J Reprod Immunol 139:103122. https://doi.org/ 10.1016/j.jri.2020.103122

44. Marchaudon V, Devisme L, Petit S, Ansart-Franquet H, Vaast P, Subtil D (2011) Chronic histiocytic intervillositis of unknown etiology: clinical features in a consecutive series of 69 cases. Placenta 32:140-145. https://doi.org/10.1016/j.placenta.2010.11.021

45. Meijer WJ, Wensing AM, Bruinse HW, Nikkels PG (2014) High rate of chronic villitis in placentas of pregnancies complicated by influenza A/H1N1 infection. Infect Dis Obstet Gynecol 2014: 768380-768385. https://doi.org/10.1155/2014/768380

46. Mekinian A, Costedoat-Chalumeau N, Masseau A, Botta A, Chudzinski A, Theulin A, Emmanuelli V, Hachulla E, De Carolis S, Revaux A, Nicaise P, Cornelis F, Subtil D, Montestruc F, Bucourt M, Chollet-Martin S, Carbillon L, Fain O, Snfmi, the
European Forum of APS (2015) Chronic histiocytic intervillositis: outcome, associated diseases and treatment in a multicenter prospective study. Autoimmunity 48:40-45. https://doi.org/10.3109/ 08916934.2014.939267

47. Mongula JE, Frenken MWE, van Lijnschoten G, Arents NLA, de Wit-Zuurendonk LD, Schimmel-de Kok APA, van Runnard Heimel PJ, Porath MM, Goossens S (2020) COVID-19 during pregnancy: non-reassuring fetal heart rate, placental pathology and coagulopathy Ultrasound. Obstet Gynecol 56:773-776. https://doi.org/10.1002/uog.22189

48. Mulvey JJ, Magro CM, Ma LX, Nuovo GJ, Baergen RN (2020) Analysis of complement deposition and viral RNA in placentas of COVID-19 patients. Ann Diagn Pathol 46:151530. https://doi.org/ 10.1016/j.anndiagpath.2020.151530

49. Ng WF, Wong SF, Lam A, Mak YF, Yao H, Lee KC, Chow KM, Yu WC, Ho LC (2006) The placentas of patients with severe acute respiratory syndrome: a pathophysiological evaluation. Pathology 38:210-218. https://doi.org/10.1080/00313020600696280

50. Parant O, Capdet J, Kessler S, Aziza J, Berrebi A (2009) Chronic intervillositis of unknown etiology (CIUE): relation between placental lesions and perinatal outcome. Eur J Obstet Gynecol Reprod Biol 143:9-13. https://doi.org/10.1016/j.ejogrb.2008.06.012

51. Patberg ET, Adams T, Rekawek P, Vahanian SA, Akerman M, Hernandez A, Rapkiewicz AV, Ragolia L, Sicuranza G, Chavez MR, Vintzileos AM, Khullar P (2020) Coronavirus disease 2019 infection and placental histopathology in women delivering at term. Am J Obstet Gynecol 224:382.e1-382.e18. https://doi.org/10. 1016/j.ajog.2020.10.020

52. Schett G, Sticherling M, Neurath MF (2020) COVID-19: risk for cytokine targeting in chronic inflammatory diseases? Nat Rev Immunol 20:271-272. https://doi.org/10.1038/s41577-020-0312-7

53. Shanes ED, Mithal LB, Otero S, Azad HA, Miller ES, Goldstein JA (2020) Placental pathology in COVID-19. Am J Clin Pathol 154: 23-32. https://doi.org/10.1093/ajcp/aqaa089

54. Sharps MC, Hayes DJL, Lee S, Zou Z, Brady CA, Almoghrabi Y, Kerby A, Tamber KK, Jones CJ, Adams Waldorf KM, Heazell AEP (2020) A structured review of placental morphology and histopathological lesions associated with SARS-CoV-2 infection. Placenta 101:13-29. https://doi.org/10.1016/j.placenta.2020.08. 018

55. Taglauer E, Benarroch Y, Rop K, Barnett E, Sabharwal V, Yarrington C, Wachman EM (2020) Consistent localization of SARS-CoV-2 spike glycoprotein and ACE2 over TMPRSS2 predominance in placental villi of 15 COVID-19 positive maternalfetal dyads. Placenta 100:69-74. https://doi.org/10.1016/j.placenta. 2020.08.015

56. Tamblyn JA, Lissauer DM, Powell R, Cox P, Kilby MD (2013) The immunological basis of villitis of unknown etiology - review. Placenta 34:846-855. https://doi.org/10.1016/j.placenta.2013.07. 002

57. Tang N, Li D, Wang X, Sun Z (2020) Abnormal coagulation parameters are associated with poor prognosis in patients with novel coronavirus pneumonia. J Thromb Haemost 18:844-847. https:// doi.org/10.1111/jth. 14768

58. Vivanti AJ, Vauloup-Fellous C, Prevot S, Zupan V, Suffee C, Do Cao J, Benachi A, De Luca D (2020) Transplacental transmission of SARS-CoV-2 infection. Nat Commun 11:3572. https://doi.org/10. 1038/s41467-020-17436-6

59. Wang W, Xu Y, Gao R, Lu R, Han K, Wu G, Tan W (2020) Detection of SARS-CoV-2 in different types of clinical specimens. JAMA. https://doi.org/10.1001/jama.2020.3786

60. Westgren M, Pettersson K, Hagberg H, Acharya G (2020) Severe maternal morbidity and mortality associated with COVID-19: the risk should not be down-played. Acta Obstet Gynecol Scand 99: 815-816. https://doi.org/10.1111/aogs. 13900 
61. World Health Organization (2020) WHO announces COVID-19 outbreak a pandemic (http://www.euro.who.int/en/health-topics/ health-emergencies/coronavirus-covid-19/news/news/2020/3/whoannounces-covid-19-outbreak-a-pandemic). http://www.euro.who. int/en/health-topics/health-emergencies/coronavirus-covid-19/ news/news/2020/3/who-announces-covid-19-outbreak-apandemic. Accessed 25/09/2020

62. Xiao F, Tang M, Zheng X, Liu Y, Li X, Shan H (2020) Evidence for gastrointestinal infection of SARS-CoV-2. Gastroenterology. https://doi.org/10.1053/j.gastro.2020.02.055

63. Yan J, Guo J, Fan C, Juan J, Yu X, Li J, Feng L, Li C, Chen H, Qiao Y, Lei D, Wang C, Xiong G, Xiao F, He W, Pang Q, Hu X,
Wang S, Chen D, Zhang Y, Poon LC, Yang H (2020) Coronavirus disease 2019 (COVID-19) in pregnant women: a report based on 116 cases. Am J Obstet Gynecol 223:111.e1-111.e14. https://doi. org/10.1016/j.ajog.2020.04.014

64. Zhu H, Wang L, Fang C, Peng S, Zhang L, Chang G, Xia S, Zhou W (2020) Clinical analysis of 10 neonates born to mothers with 2019-nCoV pneumonia. Transl Pediatr 9:51-60. https://doi.org/ $10.21037 /$ tp.2020.02.06

Publisher's note Springer Nature remains neutral with regard to jurisdictional claims in published maps and institutional affiliations. 